\title{
Bed Mulch Treatment Affects Strawberry Fruit Bronzing and Yield Performance
}

\author{
Kirk D. Larson ${ }^{1}$ \\ University of California South Coast Research and Extension Center, 7601 \\ Irvine Boulevard, Irvine, CA 92618
}

Steven T. Koike

University of California Cooperative Extension, 1432 Abbott Street, Salinas, CA 93901

Frank G. Zalom

Department of Entomology, University of California, One Shields Avenue, Davis, CA 95616

Additional index words. epidermis, Fragaria $\times$ ananassa, polyethylene mulch, solar radiation, sunscald, temperature, vegetative growth

Abstract. Strawberry plants ('Commander') were grown with different polyethylene bed mulches in the 1999-2000 and 2000-2001 production seasons to determine the effect of mulch on plant growth, yield performance and incidence of Type III strawberry fruit bronzing (T3B), a fruit disorder of unknown origin. In 1999-2000, T3B incidence ranged from $1.8 \%$ to $3.7 \%$ of total yield, and use of clear, full-bed (CFB) mulch resulted in significantly less T3B incidence than either clear center-strip mulch (CS), or yellow-on-black full-bed mulch. Plant canopy vegetative growth and shoot to root dry mass ratios were greatest for CFB compared to other mulch treatments, but there was no effect of mulch treatment on yield or fruit size. Winter temperatures in 2000-2001 were colder than in 1999-2000, with reduced vegetative growth and increased T3B incidence in spring for all mulch treatments. Use of CFB mulch resulted in greater vegetative growth, greater yield, increased fruit size and reduced T3B incidence compared to CS or green full-bed mulch, but there was no difference among mulch treatments for number of T3B fruit per plotfor any single fruit harvest interval. In 2000-2001, the onset of severe T3B symptoms on 7 May was preceded by a brief period of ambient temperatures $>31^{\circ} \mathrm{C}$. For all treatments, peak T3B incidence occurred from late May to mid-June, a period characterized by high ambient temperatures and high irradiance conditions. Results indicate that temperature and radiation are significant factors in the development of $\mathrm{T} 3 \mathrm{~B}$, and that increased plant vegetative growth in winter results in greater yields and a lower percentage of T3B-affected fruit, particularly in years with cold winters. Managing strawberry plantations to optimize plant growth and development in winter appears to be an effective strategy for reducing the severity of this disorder.

Bronzing of strawberry fruit often occurs in late spring and summer in the central coast region of California (lat. about $37^{\circ} \mathrm{N}$.), an area that produces about $40 \%$ of the US strawberry crop (Processing Strawberry Advisory Board of California, 2001). Symptoms consist of desiccation and cracking of the fruit surface, and damaged fruit is brown or yellow-brown in color, hence the term bronzing. Timing and severity vary from year to year, and differences in cultivar susceptibility have been observed, but the disorder occurs annually to some extent and can result in large economic losses due to production of excessive amounts of non-marketable fruit (Larson and Sjulin, 2001).

Received for publication 6 Jan. 2004. Accepted for publication 27 Mar. 2004. Partial financial support for this study was provided by the California Strawberry Commission. The authors thank Ed Show, Reisa Bigelow and Christina Smith for valuable assistance in conducting this study.

${ }^{1}$ To whom reprint requests should be addressed; e-mailkdlarson@ucdavis.edu.
Three distinct types of strawberry bronzing damage can be recognized (Polito et al., 2002; Larson and Sjulin, 2001). Type I bronzing results from arthropod feeding, most commonly by western flower thrips (Frankinella occidentalis Pergrande) or cyclamen mite (Phytonemus pallidus Banks), and damage occurs to the receptacle tissue beneath the calyx or around the indentations that surround the achenes (Maas, 1998). Type II bronzing results from chemical spray burn, often as a result of repeated applications of sulfur or other caustic compounds under unfavorable meteorological conditions. In both cases, bronzing occurs in localized areas of the fruit surface that have been directly exposed to arthropod feeding or chemical contact, and damage is readily correlated with recent chemical applications or arthropod activity.

In contrast, Type III fruit bronzing (T3B) covers the entire fruit surface, and is not associated with spray applications or arthropod feeding. Results of anatomical and histochemical examinations indicate that $\mathrm{T} 3 \mathrm{~B}$ damage resembles sunscald injury, and thus may be a response to heat or solar radiation injury (Polito et al., 2002). Importantly, T3B typically occurs during extended periods in spring and early summer, a time of year characterized by long days, high irradiance, high temperatures and low relative humidity. The problem also occurs more frequently inland than in cooler, overcast areas near the coast, suggesting that temperature and/or solar radiation may be important factors in the development of T3B bronzing. In addition, some California growers and researchers have observed that T3B incidence tends to be most pronounced following cold winters.

An earlier report (Larson and Sjulin, 2001) indicated that increased drip-irrigation rates resulted in reduced $\mathrm{T} 3 \mathrm{~B}$ incidence, suggesting that soil moisture deficits could contribute to the development of this disorder. In the same study, use of intermittent, midday microjet misting of plants (designed to provide evaporative cooling of the plants rather than irrigation) also resulted in reduced $\mathrm{T} 3 \mathrm{~B}$ incidence, but reductions in T3B incidence were offset by increased fruit rot and fruit malformation. These observations suggest a situation in which both environmental and physiological factors contribute to development of T3B.

Strawberry plantings in coastal California are established each autumn using bare-root transplants (Strand, 1993). For these plantings, soil and ambient temperatures during autumn and winter have marked effects on plant growth and development (Larson and Sjulin, 2001; Larson, 1994; Larson, 1997; Strand, 1993; Voth et al., 1967), and fruit yield is directly proportional to vegetative growth in late autumn and winter (Shaw, 1992; Larson and Shaw, 1995).

Cold winter temperatures that adversely affect canopy development can be expected to result in reduced shading and increased irradiance levels within the plant canopy, which could lead to increased sunscald injury (Polito et al., 2002). If so, plant vegetative growth in winter could be an important, albeit indirect, factor influencing T3B incidence. However, the relationship between plant growth in winter and T3B incidence the following spring has not been studied. The objective of this study was to determine the effect of plant vegetative growth on T3B incidence of strawberry fruit.

\section{Materials and Methods}

Field trials were conducted in commercial strawberry fields in Watsonville, Calif. $\left(36.5^{\circ} \mathrm{N}\right.$ lat.) during the 1999-2000 and 2000-2001 strawberry production seasons. Soil temperature and plant growth rates during the winter establishment period were altered by imposing various polyethylene bed mulch treatments. The trials were conducted in two different locations, both managed by the same grower and having similar cropping histories in which a cover crop of annual rye (Secale cereale L.) and bell beans (Vicia faba L.) was alternated with strawberry every other year.

Each strawberry crop was preceded by soil fumigation with a mixture of 2 methyl 
bromide: 1 chloropicrin (by weight, 392 $\mathrm{kg} \cdot \mathrm{ha}^{-1}$ ). In both years, bare-root transplants of the bronzing-susceptible cultivar 'Commander' were obtained from commercial high elevation nurseries and established either in mid-November (1999-2000 trial) or early December (2000-2001 trial) using annual hill culture. Plants were established on two-row beds with $1.22-\mathrm{m}$ centers and $0.36-\mathrm{m}$ in-row plant spacing.

Clear, full-bed (CFB) and clear, center-strip (CS) polyethylene mulches were used in both trials. For the 1999-2000 trial, we also used a full-bed, yellow-on-black (YB, consisting of two bonded layers) polyethylene film, while a full-bed green (GR) polyethylene film was used in the 2000-2001 trial. For both trials, full-bed mulches covered the top and sides of the bed, while the CS mulch was $0.30 \mathrm{~m}$ wide and covered only the surface of the bed between the two planting rows. Following standard grower practices for the 'Commander' cultivar, beds receiving center-strip mulch were left bare until mid-March in both years. Use of CS mulch was standard practice for the 'Commander' strawberry in the region, thus this material constituted the experimental control treatment.

Plants were sprinkler-irrigated during the initial establishment and early winter growth period, after which plants were irrigated using buried (2.5-cm-depth) drip-irrigation tubing. Drip irrigation was applied to all plots as per standard grower practice, typically twice per week during spring and summer, less frequently in winter.

In both years, plant growth through the end of winter was assessed by destructively harvesting plants from each mulch treatment plot on 31 Mar. for determinations of root, crown, leaf, and reproductive (bloom panicles and small fruit) tissue dry mass. In both years, this sampling date coincided with the onset of flowering and fruiting in nearly all experimental plants. Plants were dug from the field, washed, divided into component tissues, and dried at $70{ }^{\circ} \mathrm{C}$ for $4 \mathrm{~d}$ before dry mass determinations. Fruit was harvested and evaluated one to two times weekly on a plot basis to determine yield, average berry weight, and percent cull fruit due to bronzing.

Meteorological data (ambient and soil temperatures, relative humidity, irradiance) were obtained from a local meteorological station (Station \#129 in Pajaro, Calif., operated by the California Irrigation Management Information System (CIMIS) of the California Department of Water Resources).

1999-2000Trial. The experimental site was divided into four main plots, each consisting of nine adjacent beds $9.1 \mathrm{~m}$ in length. Main plots were divided into 3-bed subplots, and one of three mulch treatments was randomly assigned to each subplot: 1) CFB mulch applied 3 Jan. 2000; 2) YB mulch applied 8 Jan. 2000; and 3) CS mulch applied 15 Mar. 2000 (control treatment). Within each 3-bed mulch subplot, a single bed was randomly selected and used for all growth and fruit evaluations. With the exception of mulch treatments, plants in these selected beds were treated according to standard grower practices for 'Commander' strawberry. The soil type was an Emigdio sandy loam. Experimental design was a randomized complete block, with three mulch treatments with four replications.

Fruit harvest commenced 19 Apr. and continued twice weekly through 1 July 2000 for a total of 22 fruit harvests. On 19 May 2000, all plots were visually rated for $\mathrm{T} 3 \mathrm{~B}$ incidence by counting the total number of bronzed fruit per 9.1-m plot.

2000-2001 Trial. The experimental site was divided into four replicate blocks, each consisting of two contiguous planting beds, $1.22 \mathrm{~m}$ wide and $31.2 \mathrm{~m}$ long. Individual beds were divided into three plots, each 10.1 $\mathrm{m}$ in length on 27 Dec. 2001. Immediately thereafter, one of three mulch treatments was randomly assigned to a single plot in each block: 1) CFB mulch applied 28 Dec. 2000; 2) GR mulch applied 28 Dec. 2000; and 3) CS mulch applied 15 Mar. 2001. In addition, CS mulch was applied to the remaining three plots in each block. The soil type was a Pacheco clay loam. Experimental design was a randomized complete block, with three mulch treatments and four replications.

Fruit harvest commenced $23 \mathrm{Apr}$. and continued at about twice weekly intervals through 29 June 2001 for a total of 16 harvests. In addition to collecting the fruit yield data described previously, the number of fruit with T3B symptoms was recorded for all experimental plots for each harvest.

\section{Results and Discussion}

Plant growth determinations. Bed mulch treatment affected plant vegetative growth and development in both trial years (Table 1). Use of CFB mulch resulted in greater leaf and reproductive tissue dry matter compared to $\mathrm{CS}$, GR, or YB mulches, and greater root dry matter compared to GR and YB mulches. Use of CFB mulch also resulted in greater crown dry matter accumulation than GR or YB mulches in 2000, but did not result in enhanced crown dry matter in 2001. In our 2001 field trial, mean midday soil temperatures of CFB-, CS- (bare soil at that time of year) and GR-mulched plots at a $15-\mathrm{cm}$ depth during January 2001 were $13.3,11.3$, and $9.9^{\circ} \mathrm{C}$, respectively (data not shown).

Mulch effects on soil temperature and plant growth and yield are well-documented (Fear and Nonecke, 1989; Larson, 1997; Voth et al., 1967). Compared to colored polyethylene films, use of clear polyethylene mulch results in the greatest amount of soil warming due to a greenhouse effect (Waggoner et al., 1960). In contrast, black and dark-colored polyethylene mulches absorb much of the incident radiation while yellow, white or silver polyethylene mulches reflect much of the radiant energy back to space and therefore reduce soil temperatures (Fear and Nonecke, 1989).

For all treatments, dry mass of the various plant tissues analyzed at the end of March was considerably greater in the 1999-2000 trial than in the 2000-01 trial (Table 1). Reduced vegetative growth in the latter trial resulted from a later planting date, as well as colder soil and air temperatures during winter, 2000-01. For example, mean soil temperature $(15 \mathrm{~cm}$ depth under irrigated grass) for the December to February period in the area was 11.2 and 9.5 ${ }^{\circ} \mathrm{C}$ in 1999-2000 and 2000-01, respectively, and mean air temperature was 10.6 and $9.4^{\circ} \mathrm{C}$ in 1999-2000 and 2000-01, respectively (data not shown). These small differences in mean temperatures between years resulted in the accumulation of several thousand additional degree hours for the period 1 Dec. 1999 to 29 Feb. 2000 as compared to the same period in 2000-01.

While use of CFB generally resulted in greater plant dry mass accumulation compared to other mulches (Table 1), in both years CFB leaf dry mass increased proportionally more than CFB crown or root dry mass, resulting in greater shoot to root dry mass ratios for CFB plants compared to the GR and YB plants. For CS plants, shoot to root dry mass ratios were intermediate between GR and CFB or YB and CFB plants.

Various reports indicate that dry mass accumulation in strawberry roots reaches a relatively stable level within several months of planting, after which shoot growth or reproductive development minimize root dry mass accumulation (Forney and Breen, 1985; Galletta and Bringhurst, 1991; Larson and Shaw, 1996; Olsen et al., 1985). Apparently, as a result of increased soil temperatures and enhanced vegetative growth in winter, plants in the CFB treatment achieved this stable level of root growth before plants in the other mulch treatments. Compared to the 1999-2000 trial, dry mass accumulation to 31 Mar. was greatly reduced in the 2000-01 trial (Table 1 ), probably

Table 1. Tissue dry mass and shoot:root dry mass ratios for strawberry plants grown with three mulch treatments and destructively harvested on 30 Mar. in 1999-2000 and 2001-2002.

\begin{tabular}{lcccccc}
\hline & & \multicolumn{4}{c}{ Mean tissue dry mass $(\mathrm{g})$} \\
\cline { 3 - 6 } Year & Mulch $^{\mathrm{z}}$ & Crown & Leaf & Root & Repro $^{\mathrm{y}}$ & Shoot:root $^{\mathrm{x}}$ \\
\hline $1999-2000$ & CFB & $1.52 \mathrm{a}^{\mathrm{w}}$ & $10.52 \mathrm{a}$ & $2.75 \mathrm{a}$ & $3.79 \mathrm{a}$ & $5.39 \mathrm{a}$ \\
& CS & $0.98 \mathrm{~b}$ & $6.90 \mathrm{~b}$ & $2.30 \mathrm{ab}$ & $1.49 \mathrm{~b}$ & $4.10 \mathrm{~b}$ \\
$2000-2001$ & YB & $0.74 \mathrm{~b}$ & $4.76 \mathrm{c}$ & $1.91 \mathrm{~b}$ & $1.47 \mathrm{~b}$ & $3.34 \mathrm{~b}$ \\
& CFB & $0.65 \mathrm{a}$ & $4.70 \mathrm{a}$ & $0.99 \mathrm{a}$ & $0.95 \mathrm{a}$ & $5.85 \mathrm{a}$ \\
& CS & $0.54 \mathrm{a}$ & $3.15 \mathrm{~b}$ & $0.83 \mathrm{ab}$ & $0.42 \mathrm{~b}$ & $4.44 \mathrm{~b}$ \\
& GR & $0.47 \mathrm{a}$ & $2.22 \mathrm{~b}$ & $0.61 \mathrm{~b}$ & $0.38 \mathrm{~b}$ & $4.48 \mathrm{~b}$ \\
\hline
\end{tabular}

${ }^{\mathrm{z}} \mathrm{CS}=$ clear, center-strip polyethylene mulch (control) applied mid-March; YB = yellow-on-black, full-bed polyethylene mulch applied late December; GR = green, full-bed polyethylene mulch applied late December; $\mathrm{CFB}=$ clear, full-bed polyethylene mulch applied late December.

${ }^{y}$ Sum of flower panicle, bloom, and fruit tissue dry mass.

${ }^{x}$ Shoot (crown dry mass + leaf dry mass) to root dry mass ratio.

${ }^{\text {w}}$ Different letters within columns and years indicate significant $(P \leq 0.05)$ differences among treatments. 
as a result of a later planting date for this trial and colder mean temperatures in late autumn and winter 2000-01.

Fruit bronzing and yield performance. The 1999-2000 season was characterized by a relatively low T3B incidence in the Watsonville-Salinas area. Visual symptoms of T3B were observed in all treatments beginning in early May, with a peak incidence in mid-May and a gradual decline of symptoms thereafter. Visual ratings of T3B incidence made in the field on 19 May 2000 indicated that T3B incidence for the CS treatment was nearly 3 -fold greater than that of the CFB treatment, while incidence in the YB treatment was intermediate (Table 2).

Analysis of fruit yield for the entire 19992000 season (19 Apr. to 1 July) indicated that while yield losses due to bronzing were relatively low and ranged from $1.8 \%$ to $3.7 \%$ of total yield, mulch treatment had a significant effect on bronzing incidence (Table 3). Use of CFB mulch resulted in the least amount of $\mathrm{T} 3 \mathrm{~B}$ on a seasonal basis (1.83\% of total yield), while YB and CS mulches had significantly greater T3B incidence $(3.03 \%$ and $3.68 \%$, respectively). The CFB treatment also produced $10 \%$ and $4 \%$ more total yield than CS and YB treatments, respectively, but these differences were not significant.

The 2000-2001 central coast strawberry production season was characterized by severe bronzing in 'Commander' and other bronzesensitive cultivars, and mulch treatment had a significant effect on fruit yield, fruit mass, and T3B incidence (Table 3). Yields for CFB, CS and GR treatments were $125 \%, 100 \%$, and $70.5 \%$ of the control (CS) treatment, and fruit mass was significantly greater for the CFB treatment compared to the GR treatment. Use of CFB mulch resulted in a significantly lower percentage of T3B fruit $(11.3 \%)$ than the GR treatment $(22 \%)$, while T3B incidence for the CS treatment was intermediate $(16.5 \%)$ and not significantly different from the other two treatments.

In 2001, assessments of the number of bronzed fruit per plot for each harvest (Table 4) enabled a seasonal analysis of the occurrence of T3B for each mulch treatment. Although yields varied among mulch treatments for each harvest interval (data not shown), there was no effect of mulch treatment on the number of bronzed fruit per plot on any single harvest date (data not shown). Therefore, yields for each harvest interval were pooled across mulch treatments to facilitate an examination of seasonal trends in T3B incidence, as well as trends in ambient maximum daily temperature and solar radiation (Fig. 1). During the harvest period (15 Apr. to 29 June 2001), maximum daily temperatures generally ranged between about 15 and $25^{\circ} \mathrm{C}$, but with much higher temperatures on 7 and 30 May (31.1 and $34.7^{\circ} \mathrm{C}$, respectively). Incident solar radiation tended to increase gradually during the harvest period, generally ranging between about 250 and $365 \mathrm{~W} \cdot \mathrm{m}^{-2}$ (Fig. 1), and was greatest for the period 1 to 20 June.

Visual symptoms of T3B were first apparent in some plots of all treatments beginning May 7 (Fig. 1), and were apparent in all plots from May 17 through the end of the harvest season. Visual symptoms of T3B increased steadily from 7 to 28 May, and then decreased slightly before increasing sharply on 4 June. For all treatments, T3B incidence was greatest from 4 to 11 June, after which T3B incidence was moderate and varied between about 5 and 11 fruit per plot per harvest.

The initial development of T3B symptoms on 7 May was concomitant with a sharp increase in maximum ambient temperature on the same date (Fig. 1). Similarly, the period of maximum T3B incidence (4 to 11 June) was preceded by the highest temperature $\left(34.7^{\circ} \mathrm{C}\right)$ of the year on May 30, and this was also the period of maximum incident solar radiation (Fig. 1). Previous studies demonstrated that brown (bronze) discoloration of fruit surfaces is characteristic of sunscald injury (Barber and Sharpe, 1971), and that anatomical changes in bronzed (T3B) strawberry fruit tissues are similar to those observed in sunscalded apple (Andrews and Johnson, 1997; Polito et al., 2002). Although we obtained insufficient experimental data to determine the role of ambient temperature or solar radiation on $\mathrm{T} 3 \mathrm{~B}$ incidence, the timing of these events suggests a link between environmental conditions and T3B development and severity. Collectively, the results of these studies provide supportive evidence for a possible relationship between exposure to high temperatures or solar radiation and $\mathrm{T} 3 \mathrm{~B}$ incidence.

The inverse relation between plant leaf dry mass (Table 1) and T3B incidence (Table 3 ) in both trial years is worth noting, particularly in that symptoms of T3B injury resemble high temperature or radiation injury (Polito et al., 2002). Although canopy light and temperature regimes were not quantified in our studies, the greater leaf dry mass for plants in the CFB treatment indicates a more robust canopy that would have acted to reduce the amount of incident radiation in and around the plants. In addition to direct shading, a larger canopy would also likely reduce the amount of reflected and reradiated energy from the bed surface back up into the plant canopy.

Regardless of the underlying causal

Table 2. Effect of polyethylene bed mulch treatment on mean number of strawberry fruit per plot with visual symptoms of Type III fruit bronzing in Watsonville, Calif., 9 May 2000.

\begin{tabular}{lcc}
\hline $\begin{array}{l}\text { Bed mulch } \\
\text { tratment }\end{array}$ & $\mathrm{N}$ & $\begin{array}{c}\text { No. bronzed } \\
\text { fruit/plot }\end{array}$ \\
\hline $\mathrm{CS}$ & 4 & $54.8 \mathrm{a}^{\mathrm{y}}$ \\
YB & 4 & $33.0 \mathrm{ab}$ \\
CFB & 4 & $19.8 \mathrm{a}$ \\
\hline
\end{tabular}

${ }^{2} \mathrm{CS}=$ clear, center-strip polyethylene mulch (control) applied mid-March; YB = yellow-on-black, full-bed polyethylene mulch applied late December; $\mathrm{CFB}=$ clear, full-bed polyethylene mulch applied late December

${ }^{y}$ Different letters within columns and years indicate significant $(P<0.05)$ differences among treatments

Table 3. Mean values for seasonal fruit yield, fruit weight (g), and percent Type III fruit bronzing (T3B) as a function of three bed mulch treatments in two production seasons in Watsonville, Calif.

\begin{tabular}{lcccc}
\hline Year & $\begin{array}{c}\text { Mulch } \\
\text { treatment }^{2}\end{array}$ & $\begin{array}{c}\text { Yield } \\
\text { (\% of control) }\end{array}$ & $\begin{array}{c}\text { Fruit } \\
\text { mass }(\mathrm{g})\end{array}$ & $\begin{array}{c}\text { Fruit with T3B (\%) } \\
\text { bronzing symptoms }\end{array}$ \\
\hline $1999-2000$ & Control & $100.0 \mathrm{a}$ & $29.3 \mathrm{a}$ & $3.7 \mathrm{a}^{\mathrm{y}}$ \\
& YB & $106.3 \mathrm{a}$ & $28.5 \mathrm{a}$ & $3.0 \mathrm{a}$ \\
& CFB & $110.5 \mathrm{a}$ & $27.4 \mathrm{a}$ & $1.8 \mathrm{~b}$ \\
$2000-2001$ & Control & $100.0 \mathrm{~b}$ & $28.7 \mathrm{ab}$ & $16.5 \mathrm{ab}$ \\
& GR & $70.5 \mathrm{c}$ & $28.0 \mathrm{~b}$ & $22.0 \mathrm{a}$ \\
& CFB & $124.9 \mathrm{a}$ & $30.3 \mathrm{a}$ & $11.3 \mathrm{~b}$ \\
\hline
\end{tabular}

${ }^{2}$ Control = clear, center-strip polyethylene mulch applied mid-March; $\mathrm{YB}$ = yellow-on-black, full-bed polyethylene mulch applied late December; GR = green, full-bed polyethylene mulch applied late December; $\mathrm{CFB}=$ clear, full-bed polyethylene mulch applied late December

${ }^{y}$ Different letters within columns and years indicate significant $(P<0.05)$ differences among treatments

Table 4. Mean number of fruit per plot with Type III bronzing (T3B) symptoms for each harvest interval for three polyethylene bed mulch treatments, Watsonville, Calif., 2001.

\begin{tabular}{|c|c|c|c|c|c|c|c|c|c|c|c|c|c|c|c|c|}
\hline \multirow{2}{*}{$\begin{array}{l}\text { Mulch } \\
\text { treatment }^{y}\end{array}$} & \multicolumn{16}{|c|}{ No. of fruit with T3B symptoms } \\
\hline & \multicolumn{16}{|c|}{ Harvest no. ${ }^{z}$} \\
\hline$\overline{\mathrm{CS}}$ & $\begin{array}{c}0.5 \\
(0.4)^{\mathrm{w}}\end{array}$ & $\begin{array}{c}0.3 \\
(0.4)\end{array}$ & $\begin{array}{c}2.3 \\
(0.7)\end{array}$ & $\begin{array}{c}2.5 \\
(0.6)\end{array}$ & $\begin{array}{l}7.5 \\
(1.5)\end{array}$ & $\begin{array}{l}10.5 \\
(2.2)\end{array}$ & $\begin{array}{l}14.5 \\
(3.3)\end{array}$ & $\begin{array}{l}11.0 \\
(2.9)\end{array}$ & $\begin{array}{l}27.8 \\
(7.7)\end{array}$ & $\begin{array}{l}22.3 \\
(2.8)\end{array}$ & $\begin{array}{l}27.5 \\
(6.6)\end{array}$ & $\begin{array}{l}12.8 \\
(2.9)\end{array}$ & $\begin{array}{l}13.0 \\
(5.6)\end{array}$ & $\begin{array}{l}3.5 \\
(2.3)\end{array}$ & $\begin{array}{l}10.0 \\
(2.7)\end{array}$ & $\begin{array}{c}8.8 \\
(3.5)\end{array}$ \\
\hline CFB & $\begin{array}{c}0.8 \\
(0.4)\end{array}$ & $\begin{array}{c}0.3 \\
(0.2)\end{array}$ & $\begin{array}{l}1.5 \\
(0.4)\end{array}$ & $\begin{array}{l}2.8 \\
(0.7)\end{array}$ & $\begin{array}{l}4.8 \\
(1.0)\end{array}$ & $\begin{array}{c}4.3 \\
(1.1)\end{array}$ & $\begin{array}{c}8.0 \\
(2.7)\end{array}$ & $\begin{array}{l}7.3 \\
(1.6)\end{array}$ & $\begin{array}{l}17.8 \\
(2.3)\end{array}$ & $\begin{array}{l}25.8 \\
(1.8)\end{array}$ & $\begin{array}{l}29.5 \\
(3.0)\end{array}$ & $\begin{array}{l}12.3 \\
(3.3)\end{array}$ & $\begin{array}{c}9.3 \\
(2.0)\end{array}$ & $\begin{array}{c}4.0 \\
(1.3)\end{array}$ & $\begin{array}{c}7.8 \\
(2.1)\end{array}$ & $\begin{array}{c}6.0 \\
(2.1)\end{array}$ \\
\hline GR & $\begin{array}{c}0.3 \\
(0.2)\end{array}$ & $\begin{array}{c}0.8 \\
(0.4)\end{array}$ & $\begin{array}{c}0.3 \\
(0.2)\end{array}$ & $\begin{array}{l}1.0 \\
(0)\end{array}$ & $\begin{array}{c}4.8 \\
(1.6)\end{array}$ & $\begin{array}{c}4.3 \\
(0.9)\end{array}$ & $\begin{array}{l}17.8 \\
(3.4)\end{array}$ & $\begin{array}{l}14.5 \\
(3.5)\end{array}$ & $\begin{array}{l}28.5 \\
(3.7)\end{array}$ & $\begin{array}{l}21.5 \\
(3.8)\end{array}$ & $\begin{array}{l}28.0 \\
(1.1)\end{array}$ & $\begin{array}{c}9.8 \\
(1.0)\end{array}$ & $\begin{array}{c}8.5 \\
(3.4)\end{array}$ & $\begin{array}{c}7.3 \\
(2.2)\end{array}$ & $\begin{array}{l}15.8 \\
(4.1)\end{array}$ & $\begin{array}{c}5.8 \\
(1.2)\end{array}$ \\
\hline
\end{tabular}

${ }^{2}$ Harvest 1 = 7 May 2001; harvest $16=29$ June 2001.

${ }^{y} \mathrm{CS}=$ clear, center-strip polyethylene mulch (control) applied mid-March; GR = green, full-bed polyethylene mulch applied late December; CFB $=$ clear, fullbed polyethylene mulch applied late December.

"Standard deviation in parentheses. 


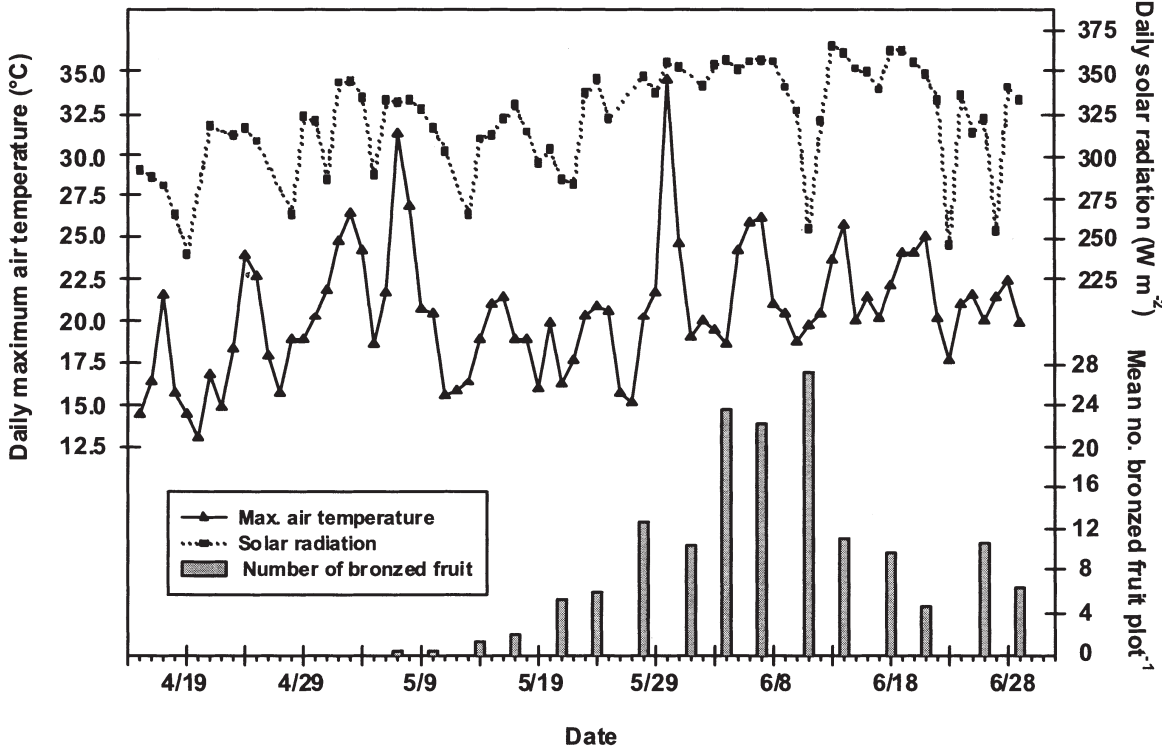

Fig. 1. Daily solar radiation, maximum daily air temperature, and mean number of mature, harvested fruit with Type III bronzing symptoms, Watsonville, Caif., April to June 2001.

mechanisms of T3B, use of crop management practices that optimize strawberry plant growth and development in winter will result in greater yields and reduced T3B fruit bronzing in California's central coast region, particularly in years characterized by colder than average winter temperatures.

\section{Literature Cited}

Andrews, P.K. and J.R. Johnson. 1997. Anatomical changes and antioxidant levels in the peel of sunscald damaged apple fruit. Plant Physiol. 114:103 (abstr.).

Barber, H.N. and P.J.H. Sharpe. 1971. Genetics and physiology of sunscald fruit. Agr. Meteorol. 8:175-191.
Cannell, G.H., V. Voth, R.S. Bringhurst, and E.L. Proebsting. 1961. The influence of irrigation levels and application methods, polyethylene mulch, and nitrogen fertilization on strawberry production in southern California. Proc. Amer. Soc. Hort. Sci. 78:281-291.

Fear, C.D. and G.R. Nonecke. 1989. Soil mulches influence reproductive and vegetative growth of 'Fern' and 'Tristar' day-neutral strawberries. HortScience 24:912-913.

Forney, C.F. and P.J. Breen. 1985. Dry matter partitioning and assimilation in fruiting and deblossomed strawberry. J. Amer. Soc. Hort. Sci. 110:181-185.

Galletta, G.J. and R.S. Bringhurst. 1991. Strawberry management. In: G.J. Galletta and D.G. Himelrick (eds.). Small fruit crop management. chapter
3. Prentice Hall, Ingelwwod Cliffs, N.J.

Larson, K.D. and T.M. Sjulin. 2001. Influence of polyethylene bed mulch, drip irrigation rate, and intermittent overhead sprinkling on strawberry fruit bronzing. HortScience 36:433 (abstr.).

Larson, K.D. and D.V. Shaw. 1996. Soil fumigation, fruit production and dry matter partitioning of field-grown strawberry plants. J. Amer. Soc. Hort. Sci. 121:1137-1140.

Larson, K.D. 1994. Strawberry, p. 271-297. In: B. Schaffer and P.C. Andersen (eds.). Handbook of environmental physiology of fruit crops. vol. 1. Temperate fruits. CRC Press, Boca Raton, Fla.

Larson, K.D. 1997. Polyethylene mulch, diurnal and seasonal soil temperatures, and growth and yield of strawberries in southern California. HortScience 31:504.

Maas, J.L. (ed.). Compendium of strawberry diseases. Amer. Phytopathol. Soc., St. Paul, Minn.

Olsen, J., L.W. Martin, P.J. Pelofske, P.J. Breen, and C.F. Forney. 1985. Functional growth analysis of the strawberry. J. Amer. Soc. Hort. Sci. 110:89-93.

Polito, V.S., K.D. Larson, and K. Pinney. 2002. Anatomical and histochemical factors associated with bronzing development in strawberry fruit. J. Amer. Soc. Hort. Sci. 127:355-357.

Shaw, D.V. 1992. Genetic correlations between vegetative growth traits and productivity at different within-season intervals for strawberries (Fragaria $\times$ ananassa). Theor. Appl. Genet. 85:100-109.

Strand, L.L. 1993. Integrated pest management for strawberries. Univ. Calif. Div. Agr. Nat. Res. Publ. 3351.

Voth, V., R.S. Bringhurst, and H.J. Bowen. 1967. Effect of bed system, bed height and clear polyethylene mulch on yield, salt accumulation and soil temperature in California strawberries. Proc. Amer. Soc. Hort Sci. 91:242-248.

Waggoner, P.E., P.M. Miller, and H.C. De Roo. 1960. Plastic mulching_Principles and benefits. Conn. Agr. Expt. Sta. (New Haven) Bul. No. 634. 